\title{
TOXICITY OF MONOSODIUM GLUTAMATE ON MALE RAT REPRODUCTIVE SYSTEM AND EFFECT OF CURCUMIN AND PROPOLIS CO-ADMINISTERATION
}

\author{
Aml A. Mohamed*, Hayam Z. Thabet* and Amal M. Abdel-hafez** \\ *Department of forensic medicine and clinical toxicology, ** Department of Histology \\ Faculty of medicine, Assiut University
}

\begin{abstract}
The safety of monosodium glutamate (MSG) usage has generated much controversy locally and globally. MSG is known to affect the structure and function of male reproductive system as well as fertility. The aim of the present work was to study the toxic effect of MSG on reproductive system of adult male albino rats and to determine the possibility to reverse this effect using curcumin and propolis. Seventy sexually mature male albino rats were used for this study and divided into 7 groups. The first 3 were control groups administered (distelled water, curcumin, and propolis), the 4th group was the experimental and administered MSG at a dose of $4 \mathrm{~g} / \mathrm{kg}$ body weight for $6 \mathrm{ws}$, the $5^{\text {th }}$ and $6^{\text {th }}$ groups, MSG was co-administered with curcumin or propolis at the doses of $10 \mathrm{mg}$, and $50 \mathrm{mg} / \mathrm{kg}$ body weight respectively and the $7^{\text {th }}$ group received combination of MSG, curcumin and propolis. It was found that MSG has adverse impacts on male rat reproduction including decrease testicular weight, with histological structure alternation, decrease sperm count and plasma level of testosterone and luteinizing hormone (LH). Coadministration of curcumin and propolis either separately or combined ameliorate these effects where testicular weight and structure of seminiferous tubules with their lumens full of sperms were regained compared to MSG treated animals. Sperm count; testosterone and LH levels were improved.
\end{abstract}

Key words: MSG, Curcumin, Propolis, male rat reproductive system.

E-mail of the corresponding author: aml_aly@yahoo.com

Other authors' emails: hayamthabet@yahoo.com, amarzouk69@yahoo.com

\section{INTRODUCTION}

Monosodium L- glutamate (MSG) is a major flavor enhancer used as a food additive; its concentrations vary in different foods (Walker et al., 2000). Nowadays, toxicity and the safe concentration of MSG in human's food is still a controversial issue (Beyreuther et al., 2007). In animal studies, MSG at higher doses was demonstrated to be a neurotoxic salt that could alter the hypothalamic-pituitary-adrenal axis
(HPA) and cause damage to neurons in the hypothalamic nuclei. This is a pointer to the fact that MSG may alter the neural control of reproductive hormone secretion via the hypothalamic-pituitarygonadal regulatory axis. Such alterations in reproductive hormone secretion may adversely affect the reproductive capacity of the affected animals (Seo et al., 2010). Those findings imply that free glutamate dissociated from MSG may act on their specific receptors in the central neurons or some peripheral cells, 
resulting in their pathological alterations. Recently several reports have been indicating that administration of MSG may affect the sperm count in both neonatal and adult animals (Igwebuike et al., 2011) and the glutamate receptors and transporters are expressed in the testis and sperm of mice, rats, and humans (Hu et al., 2004).

Natural antioxidants strengthen the endogenous antioxidants defenses and restore the optimal balance by neutralizing reactive species (Heeba and Abd-Elghany, 2010). Curcumin is one of the naturally occurring dietary substances; it has been used since ancient times as medical plant for promoting human health. It is an important constituent of rhizomes of the plant Curcuma longa which is a member of the family (Zingiberaceae). Curcumin is used as a spice to give specific yellow color and flavor to Curry (Pari et al., 2008). It represents a class of antioxidant and anti-inflammatory having a potent inhibitor effect on reactive oxygen species (ROS) formation (Ruby et al., 2005). Curcumin was found to have a variety of biological activities including antitumor (Ströfer et al., 2012) and antiviral activities (Mazumder et al., 1995). Several animal studies proved the protective effects of curcumin against hazardous chemicals (Farombi et al., 2007).

Propolis is a natural resinous mixture produced by honey bees from substances collected from parts of plants, buds, and exudates. Since ancient times propolis has been extensively employed by man, especially in folk medicine to treat several diseases. Ancient Egyptians used bee glue to embalm their cadavers
(Bankova et al., 2000). Nowadays it was used in foods and healthy drinks to improve well-being and treat diseases such as inflammation, diabetes, heart disease and even cancer. Propolis, contains a mixture of polyphenols, flavonoid aglycones, minerals, vitamins and amino acids (Khalil, 2006). Its flavonoid content is responsible for the antioxidant activity that is capable of scavenging free radicals and protection against lipid peroxidation (Yousef and Salama, 2009) and also through activation of antioxidant enzymes such as superoxide dismutase (Jasprica et al., 2007) and catalase (CAT) against free radicals (Sobocanec et al., 2006). Propolis has protective effect against infertility as it improves sperm production, count, motility and quality, and increases the process of steroidogenesis and hence testosterone production (Yousef and Salama, 2009).

The present study was undertaken to evaluate toxic effect of MSG on reproductive system of adult male albino rats and to determine the role of curcumin and propolis to ameliorate these effects.

\section{MATERIALS AND METHODS}

Chemicals:

- Monosodium Glutamate (MSG): was obtained from El Dawlia for Medical Equipments and Chemicals Co. Egypt.

- Curcumin Extract: curcumin were purchased from Sigma Chemical Co. (St. Louis, Mo, USA).

- Propolis was obtained from El Dawlia for Medical Equipments and Chemicals Co. Egypt. 
-Testosterone and LH ELIZA kit: were obtained from Biocheck, Inc (323 Vintage park drive, Foster City, CA 94404).

Animals: 70 sexually mature male albino rats about 6 weeks old (Sengupta, 2011), with initial body weight $150: 160 \mathrm{~g}$ were used. The animals were diseasefree, obtained from animal house Faculty of Medicine, Assiut University. Animals were housed in cleaned and good aerated metal cages ( 5 per cage) and they were allowed free access to rodent laboratory food and water throughout the experiment. The housing facility was kept under laboratory constant conditions of temperature $\left(24 \pm 2{ }^{\circ} \mathrm{C}\right)$, with a 12 hour light, 12 hour dark cycle under a controlled humidity environment.

The experimental protocol was approved by the Institutional Animal Research Committee of the Faculty of Medicine, Assiut University, Egypt. It was carried out in accordance with the published guidelines and regulations for the use and care of animals.

Treatment protocols: Animals were randomly distributed by weight and divided into 7 groups, 10 rats each: In group I (control DW) animals were given $1 \mathrm{ml}$ distilled water, group II (control curcumin) animals were given curcumin at a dose of $10 \mathrm{mg} / \mathrm{kg} /$ day dissolved in distilled water, group III (control propolis) received propolis at a dose of $50 \mathrm{mg} / \mathrm{kg} /$ day dissolved in distilled water. Group VI (MSG group) animals received MSG at a dose of $4 \mathrm{~g} / \mathrm{kg} /$ day which equal (1/3) oral LD50 of rats (Material Safety Data Sheet, 2013) dissolved in distilled water. Group V (MSG + curcumin), Group VI (MSG + propolis) and group VII (MSG + curcumin + propolis). The choice of doses of curcumin and propolis were based on the results of previous study of Fetouh and Azab, (2014).

Solutions of these chemicals were freshly prepared before administration and were formed by dissolving the amount of substance needed to reach the reference dose in distilled water. The chemical concentrations were adjusted per animals' respective weight so that each animal received $1 \mathrm{ml}$ solution from the needed chemical orally through a gastric tube once daily for 6 weeks.

Weight of animals was measured and recorded at the beginning of the study, after 3 weeks and at the end of the experiment and compared as a percent ratio from the control distilled water group.

By the end of the experiment, animals were anaesthetized by pentobarbitone sodium (40 $\mathrm{mg} / \mathrm{kg}$, i.p) and sacrificed by cervical dislocation.

Histological preparations: The testis were dissected out, cleaned and grossly examined for any changes then trimmed from tunica vaginalis and epididymis, weighed and then fixed by immersion in Bouin's fluid for 48 hours. Later, they were dehydrated in graded concentrations of ethanol, cleared in xylene, and embedded in paraffin wax. Sections of $5 \mu \mathrm{m}$ thick were cut, mounted on glass slides, and stained with hematoxylin and eosin for light microscopy. Photomicrographs were captured using a Nikon light ECLIPSE E200 microscope equipped with a DXM1200 digital camera.

Epididymal Sperm Concentration: The epididymis of each rat was used for the determination of epididymal sperm 
concentration. The epididymis were minced in $1 \mathrm{ml}$ phosphate buffered saline (PBS, PH 7.4) and filtered through $80 \mathrm{~m}$ nylon mesh to obtain filtrate. The sperm count was conducted using Neubauer haemocytometer (França et al, 2005).

Biochemical Assays: For hormones determination, blood samples $(2 \mathrm{ml})$ were collected from the inferior vena cava immediately after scarification; heparin was added as an anticoagulant and then centrifuged. Plasma was stored frozen at $-20{ }^{\circ} \mathrm{C}$ until used for testosterone and LH assay. The assay was carried out using ELISA technique.

Statistical analysis: Statistically analyzed using Graph Pad Prism software (version 4.03). The data were expressed as mean \pm SD from animals per group. The difference between the groups was compared for statistical significance by student $t$ test with the level of significance set at $* * * \mathrm{p}<0.001$, $* * \mathrm{p}<0.01$ and $* \mathrm{p}<0.05$

\section{RESULTS}

\section{Body weight:}

Growth assessment for all groups was presented in Table (1). The initial body weights were approximated among the studied groups. Time dependent steady increase in body weight was observed in the control groups and in groups treated MSG in concomitant with curcumin and propolis either separately or together throughout the study period. MSG treated group showed significant increase in weight gain until the middle of the study (3 weeks) compared with the percent difference from control group (104.5\%), after which a significant decrease in body weight was observed at the end of the study (6 weeks) compared with the percent difference from control group $(93.1 \%)$.

\section{count: \\ Testicular weight and sperm}

Gross examination of the testis revealed that, no marked differences were found in the shape and surface features among the studied groups of rats in comparison with the control groups. The testicular weight and sperm count of all groups was measured (Table 2). No significant testicular weight or sperm count differences were found among the three control groups, values of group I (DW control group) was used for comparison with treated groups. Significant decrease in testicular weight and sperm count were found in MSG, $\mathrm{MSG}+$ Curcumin, MSG + Propolis and in $\mathrm{MSG}+$ Curcumin + Proplis groups compared with DW control group ( $>0.001)$. Significant increase in testicular weights and sperm count were noticed after co-administration of curcumin, propolis separately or together compared with MSG group ( $p>0.001)$.

\section{Plasma Testosterone and LH levels:}

High significant decrease in plasma levels of testosterone $(\mathrm{ng} / \mathrm{ml})(\mathrm{p}>0.001)$ in $\mathrm{MSG}, \mathrm{MSG}+$ Curcumin, $\mathrm{MSG}+$ Propolis and in $\mathrm{MSG}+$ Curcumin + Proplis treated groups compared to control groups. Testosterone levels showed highly significant increase ( $p>0.001) \quad$ after concomitant administration of curcumin and propolis either separately or together compared with MSG group as shown in Fig. (1).

High significant decrease of plasma levels of $\mathrm{LH}(\mathrm{ml} \mu / \mathrm{ml})$ in MSG treated groups $(\mathrm{P}<0.001)$ and significant decrease in MSG + Curcumin, MSG + 
Propolis and in MSG + Curcumin + Proplis treated groups $(\mathrm{p}>0.01)$ compared to control groups. LH levels showed significant increase $(\mathrm{p}<0.05)$ in
MSG + curcumin + Propolis treated group compared with MSG group as shown in Fig. (2).

Table (1): The body weight (grams) and survival rate in the different groups of rats.

\begin{tabular}{|c|c|c|c|c|c|c|c|}
\hline $\begin{array}{l}\text { Body } \\
\text { weight (g) }\end{array}$ & $\begin{array}{c}\text { Group } \\
\text { I } \\
\text { control } \\
\text { DW }\end{array}$ & $\begin{array}{l}\text { Group II } \\
\text { Control } \\
\text { Curcumin }\end{array}$ & $\begin{array}{c}\text { Group } \\
\text { III } \\
\text { Control } \\
\text { Propolis }\end{array}$ & $\begin{array}{c}\text { Group } \\
\text { IV } \\
\text { MSG }\end{array}$ & $\begin{array}{c}\text { Group V } \\
\text { MSG+ } \\
\text { Curcumin }\end{array}$ & $\begin{array}{c}\text { Group } \\
\text { VI } \\
\text { MSG+ } \\
\text { Propolis }\end{array}$ & $\begin{array}{c}\text { Group } \\
\text { VII } \\
\text { MSG+ } \\
\text { Curcumin } \\
\text { +Propolis }\end{array}$ \\
\hline Initial body weight (g) & $\begin{array}{c}1 \\
52 \pm 3.9\end{array}$ & $\begin{array}{c}1 \\
59.2 \pm 3.2\end{array}$ & $\begin{array}{c}1 \\
54.7 \pm 2.2\end{array}$ & $\begin{array}{c}1 \\
53 \pm 2.9\end{array}$ & $\begin{array}{c}1 \\
56.3 \pm 2.3\end{array}$ & $\begin{array}{c}1 \\
57.3 \pm 1.7\end{array}$ & $\begin{array}{c}1 \\
54.2 \pm 2.9\end{array}$ \\
\hline Body we & $\begin{array}{l}202 \pm 1.8 \\
(100 \%)\end{array}$ & $\begin{array}{l}205 \pm 1.4 \\
(101.5 \%)\end{array}$ & $\begin{array}{l}203 \pm 2.6 \\
(100.5 \%)\end{array}$ & $\begin{array}{l}211 \pm 1.1 \\
(104.5 \%)\end{array}$ & $\begin{array}{l}207 \pm 3.1 \\
(102.5 \%)\end{array}$ & $\begin{array}{l}206 \pm 2.4 \\
(101.9 \%) \\
\end{array}$ & $\begin{array}{l}205 \pm 1.7 \\
(101.5 \%)\end{array}$ \\
\hline Final body weight (g) & $\begin{array}{l}248 \pm 1.7 \\
(100 \%)\end{array}$ & $\begin{array}{l}251 \pm 3.1 \\
(101.2 \%)\end{array}$ & $\begin{array}{l}249 \pm 1.8 \\
(100.4 \%)\end{array}$ & $\begin{array}{l}231 \pm 4.6 \\
(93.1 \%)\end{array}$ & $\begin{array}{l}239 \pm 2.5 \\
(96.4 \%)\end{array}$ & $\begin{array}{l}237 \pm 0.7 \\
(95.6 \%)\end{array}$ & $\begin{array}{l}244 \pm 4.1 \\
(98.4 \%)\end{array}$ \\
\hline Surviv & $\begin{array}{l}10 \text { of } 10 \\
(100 \%)\end{array}$ & $\begin{array}{l}10 \text { of } 10 \\
(100 \%)\end{array}$ & $\begin{array}{l}10 \text { of } 10 \\
(100 \%)\end{array}$ & $\begin{array}{l}8 \text { of } 10 \\
(80 \%)\end{array}$ & $\begin{array}{l}9 \text { of } 10 \\
(90 \%)\end{array}$ & $\begin{array}{l}8 \text { of } 10 \\
(80 \%)\end{array}$ & $\begin{array}{l}9 \text { of } 10 \\
(90 \%)\end{array}$ \\
\hline
\end{tabular}

Values represent mean $\pm \mathrm{SE}$ and were analyzed by a t -test ( $\mathrm{n}=8: 10$ per group). $\%=$ percentage difference from control (DW).

Table (2): Change in mean value of testis weights in rats and sperm count in different groups:

\begin{tabular}{|c|c|c|c|c|c|c|c|}
\hline Groups & $\begin{array}{c}\text { Group I } \\
\text { Control } \\
\text { DW }\end{array}$ & $\begin{array}{c}\text { Group II } \\
\text { Control } \\
\text { Curcumi } \\
\text { n }\end{array}$ & $\begin{array}{c}\text { Group } \\
\text { III } \\
\text { Control } \\
\text { Propolis }\end{array}$ & $\begin{array}{l}\text { Group } \\
\text { IV } \\
\text { MSG }\end{array}$ & $\begin{array}{c}\text { Group } \\
\text { V } \\
\text { MSG+ } \\
\text { Curcum } \\
\text { in }\end{array}$ & $\begin{array}{c}\text { Group } \\
\text { VI } \\
\text { MSG+ } \\
\text { Propolis }\end{array}$ & $\begin{array}{l}\text { GroupV } \\
\text { II } \\
\text { MSG+ } \\
\text { Curcum } \\
\text { in } \\
+ \text { Propol } \\
\text { is }\end{array}$ \\
\hline $\begin{array}{l}\text { Testicul } \\
\text { ar } \\
\text { weight } \\
\text { (g) }\end{array}$ & $\begin{array}{c}1.682 \\
\pm \\
0.050\end{array}$ & $\begin{array}{c}1.62 . \\
\pm \\
0.032\end{array}$ & $\begin{array}{c}1.647 \\
\pm \\
0.028\end{array}$ & $\begin{array}{c}1.284 \\
\pm \\
0.019 \\
* * *\end{array}$ & $\begin{array}{c}1.511 \\
\pm \\
0.135 \\
* * * \\
\# \# \#\end{array}$ & $\begin{array}{c}1.467 \\
\pm \\
0.007 \\
* * * \\
\# \# \#\end{array}$ & $\begin{array}{c}1.589 \\
\pm \\
0.197 \\
* * * \\
\# \# \#\end{array}$ \\
\hline $\begin{array}{l}\text { Sperm } \\
\text { count } \\
\left(\mathbf{1 0}^{6} / \mathbf{m l}\right)\end{array}$ & $5.7 \pm 0.3$ & $5.5 \pm 0.4$ & $5.4 \pm 0.1$ & $\begin{array}{c}3.8 \pm 0.2 \\
* * *\end{array}$ & $\begin{array}{c}4.7 \pm 0.6 \\
* * * \\
\# \# \#\end{array}$ & $\begin{array}{c}4.5 \pm 0.3 \\
* * * \\
\# \# \#\end{array}$ & $\begin{array}{c}4.9 \pm 0.4 \\
* * * \\
\# \# \#\end{array}$ \\
\hline
\end{tabular}

$(* * *)$ Significant at $\mathrm{p}<0.001$ compared to control group.

(\#\#\#) Significant at $\mathrm{p}<0.001$ compared to MSG group. 


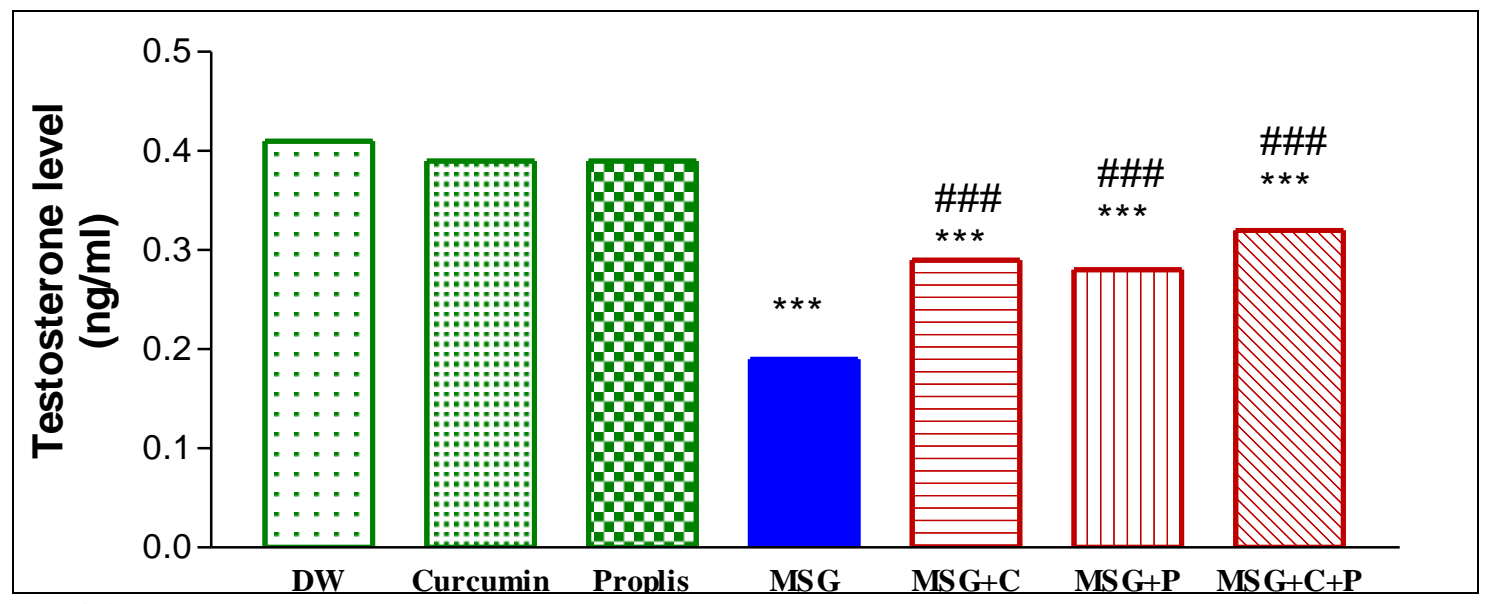

Figure (1): Testosterone plasma level $(\mathrm{ng} / \mathrm{ml})$ in animal groups.

$* * *$ : Significant differences as compared to control group $(\mathrm{P}<0.001)$

\#\#\#: Significant differences as compared to MSG treated group $(\mathrm{P}<0.001)$

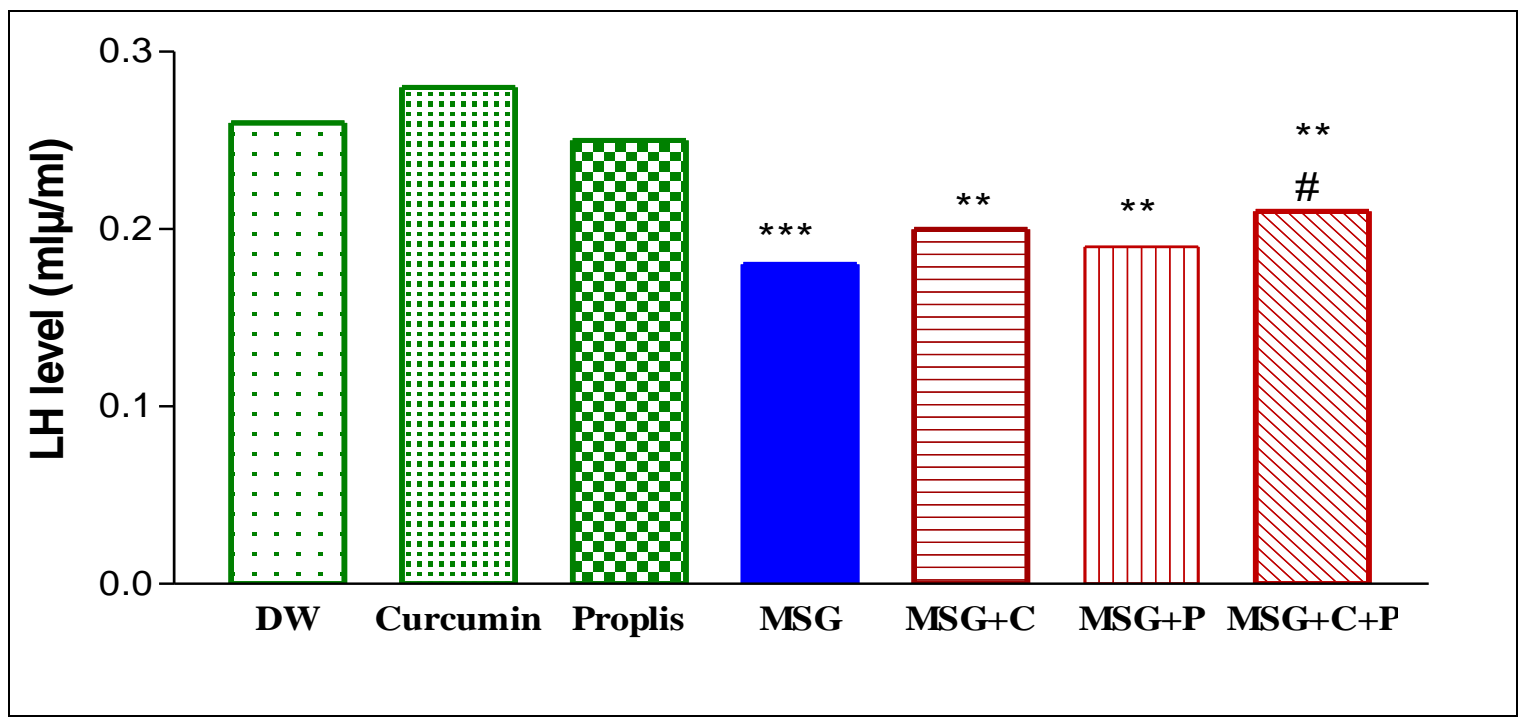

Figure (II): LH plasma level $(\mathrm{ml} \mu / \mathrm{ml})$ in animal groups.

***: Significant differences as compared to control group ( $\mathrm{P}<0.001)$.

$* *$ : Significant differences as compared to control group $(\mathrm{P}<0.01)$.

\#: Significant differences as compared to MSG treated group $(\mathrm{P}<0.05)$.

Histological Observations:

Histological sections of testis from all control groups stained by $\mathrm{H} \& \mathrm{E}$ showed the normal structure of seminiferous tubules which appear rounded or oval surrounded by regular thin basal lamina. The tubules were lined by stratified germinal epithelium, which consists of two distinct populations of cells; the spermatogenic cells and the sertoli cells. Sertoli cells appeared as elongated cells, with poorly defined irregular outline and oval basal nuclei. The spermatogenic cells showed different stages of spermatogenesis, with the spermatogonia resting on the basal 
lamina and having small and dark nuclei, while the primary spermatocytes appeared as large cells with large oval nuclei inner to the spermatogonia. Secondary spermatocytes were difficult to be detected in the spermatogenic epithelium. The spermatids were detected at their different steps of spermiogenesis. Tufts of spermatozoa appeared in the lumen of the seminiferous tubules. In-between the tubules, the interstitial tissue present blood capillaries with clusters of cells with ovoid or polygonal shape and spherical nuclei representing the leydig cells (Fig. 1a \& 1b).

$\mathrm{H} \& \mathrm{E}$ stained sections of the testis in the MSG treated group (Fig. 2a \& 2b) displayed variable degree of histopathological alterations and distortion of the normal appearance of the testis, the seminiferous tubules showed atrophy, deformed germ cells with pyknotic nuclei and many sertoli cells having densely stained nuclei and cytoplasm. Most spermatogenic cells showed degeneration and/or necrosis. Necrosis was in the form of pale or vacuolated cytoplasm.

Many vacuoles were seen among the spermatogenic cells. There was separation between germ cells and surrounding myoid cells. Interstitial tissue appeared damaged and showed hemorrhage. Leydig cells were markedly decreased in number and had pyknotic nuclei.

Fig. 3a \& 3b showed section in testis of MSG and curcumin treated group, revealed preservation of the structure of many seminiferous tubules with wellorganized spermatogenic lining epithelium and improved interstitial tissue. Some spermatogenic cells in the lumen of some seminiferous tubules showed mild sloughing. Few germ cells with pyknotic nuclei were seen, Leydig cells appeared normal with absence of hemorrhage in the interstitial tissue.

Fig. 4a \& 4b: Section in testis of rat treated with MSG and Proplis demonstrated different degrees of restoration of seminiferous tubules with organized spermatogenic lineage. Preserved Leydig cells but still there were some vacuoles; cells with dense pyknotic nuclei and limited intertubular hemorrhage were seen.

Fig. 5a\&5b: Section in testis of a rat treated with MSG, curcumin and Proplis revealed good restoration of most seminiferous tubules and interstitial tissue. Minimal and hardly detected sloughing of germ cells, with relatively normal appearance of spermatogenic cells and Leydig cells. 


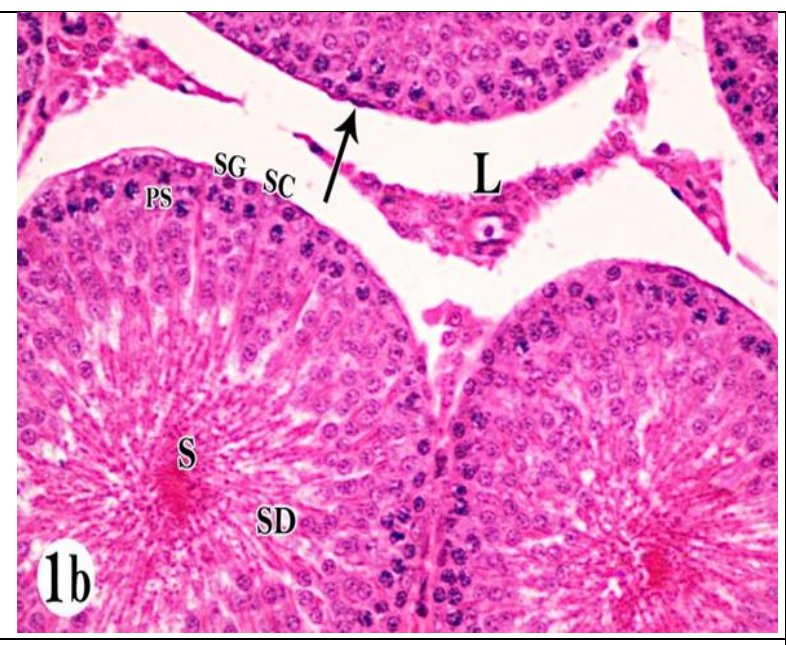

Figure (1a): Section in testis of a control rat showing normal seminiferous tubules (ST) with regular basal lamina (arrow) and clumps of interstitial cells of Leydig (L). (H\&E x 100)

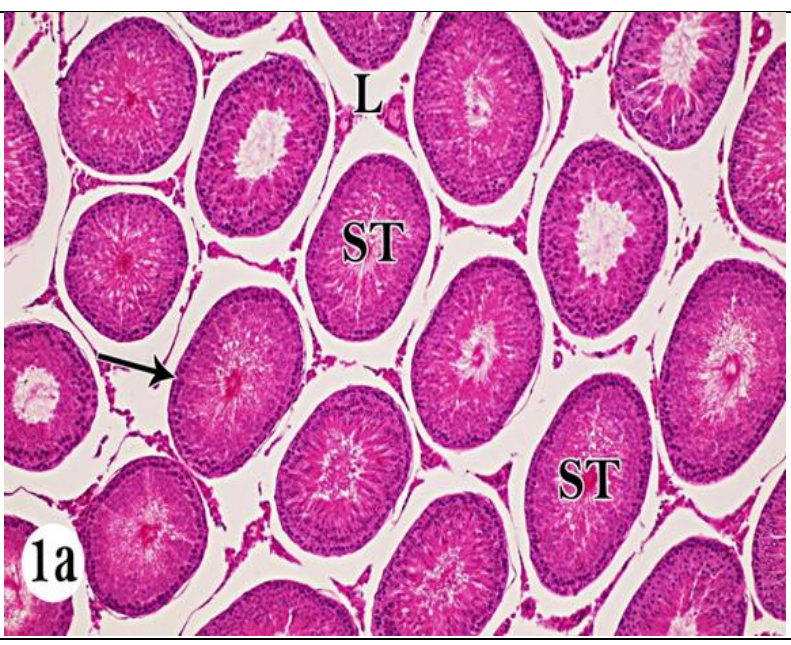

Figure (1b): Section in testis of a control rat showing portions of seminiferous tubules

surrounded by myoid cells (arrow). Notice the spermatogonia (SG), primary spermatocytes (PS), spermatids (SD), spermatozoa (S), Sertoli cells (SC) and Leydig cells (L). (H\&E x400)

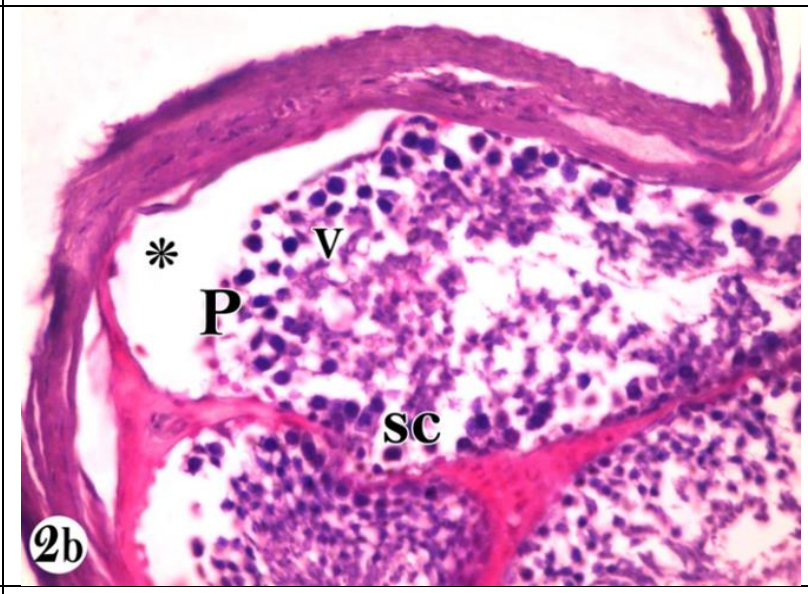

Figure (2b): Section in testis of a rat treated with MSG. The seminiferous tubules reveal deformed germ cells with pyknotic nuclei $(\mathrm{P})$ and many Sertoli cells (SC) with densely stained nuclei. Many vacuoles (V) are seen between germ cells. Notice the separation $\left(^{*}\right)$ between germ cells and surrounding myoid cells. Interstitial tissue appeared damaged and show hemorrhage. (H\&E x400) 


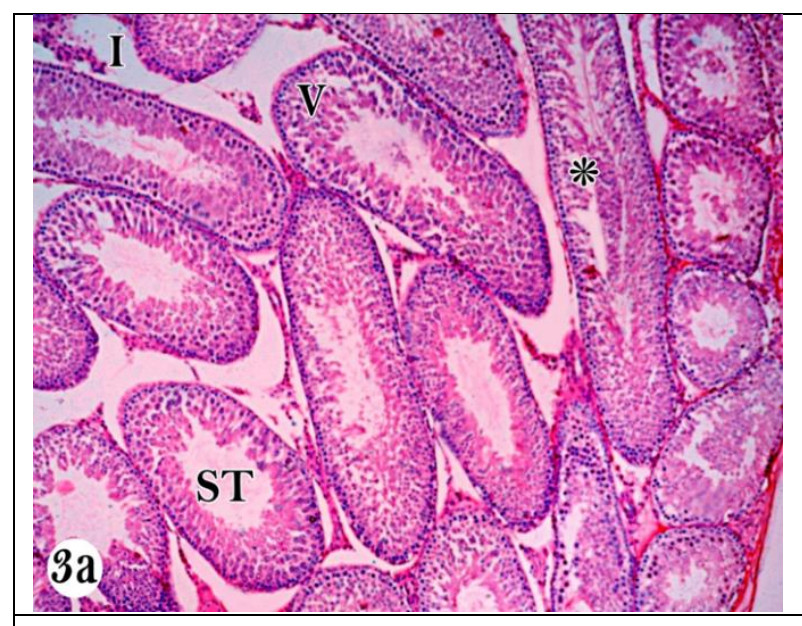

Figure (3a): Section in testis of a rat treated with MSG and curcumin showing preservation of the structure of many seminiferous tubules (ST) and improved interstitial tissue (I). Few vacuoles (V) are seen. Notice the sloughed spermatogenic cells $(*)$ in the lumen of some seminiferous tubules. (H\&E x100)

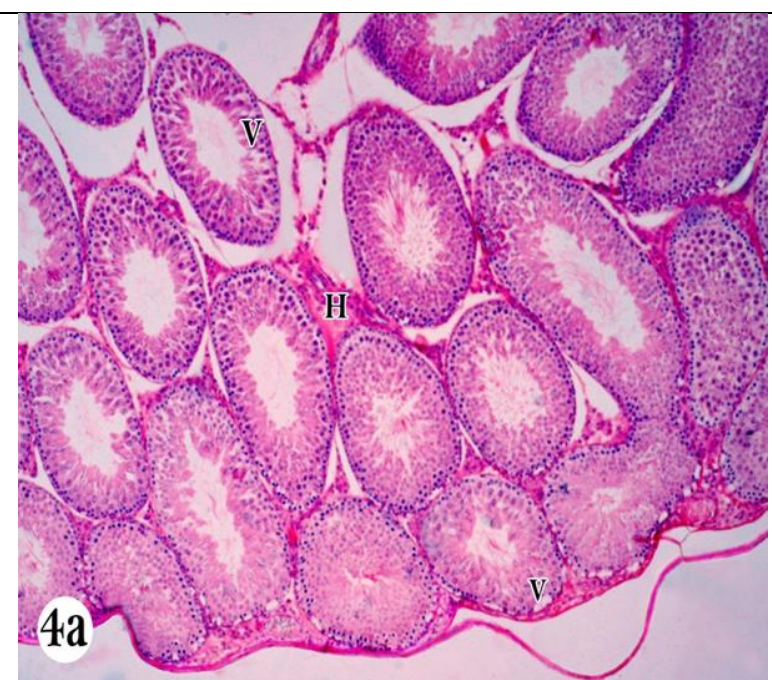

Figure (4a): Section in testis of a rat treated with MSG and Propolis showing different degrees of preservation of seminiferous tubules. Some vacuoles (V) and limited intertubular hemorrhage $(\mathrm{H})$ are seen. (H\&E x100)

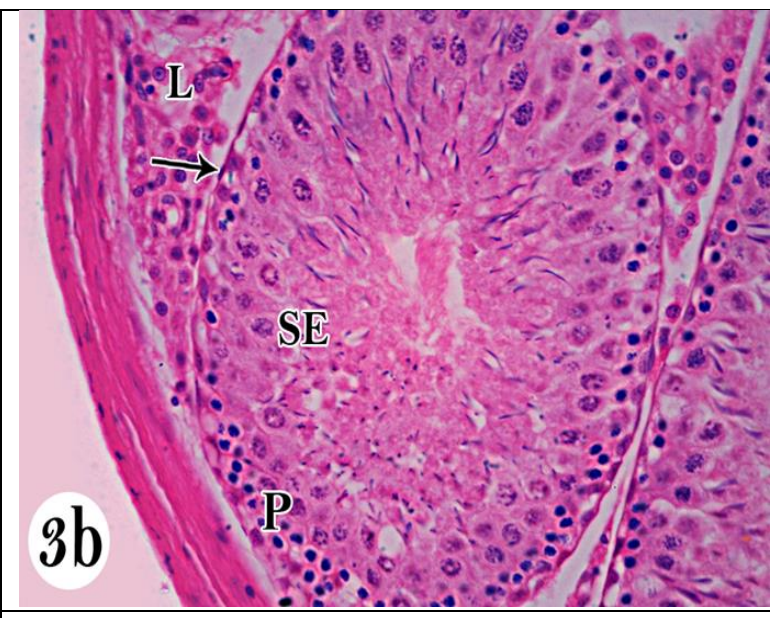

Figure (3b): Section in testis of a rat treated with MSG and curcumin showing wellorganized spermatogenic lining epithelium (S), normal basal lamina (arrow). Few germ cells with pyknotic nuclei are seen (P). Notice normal Leydig cells (L) and absence of hemorrhage in the interstitial tissue (SE). (H\&E x400)

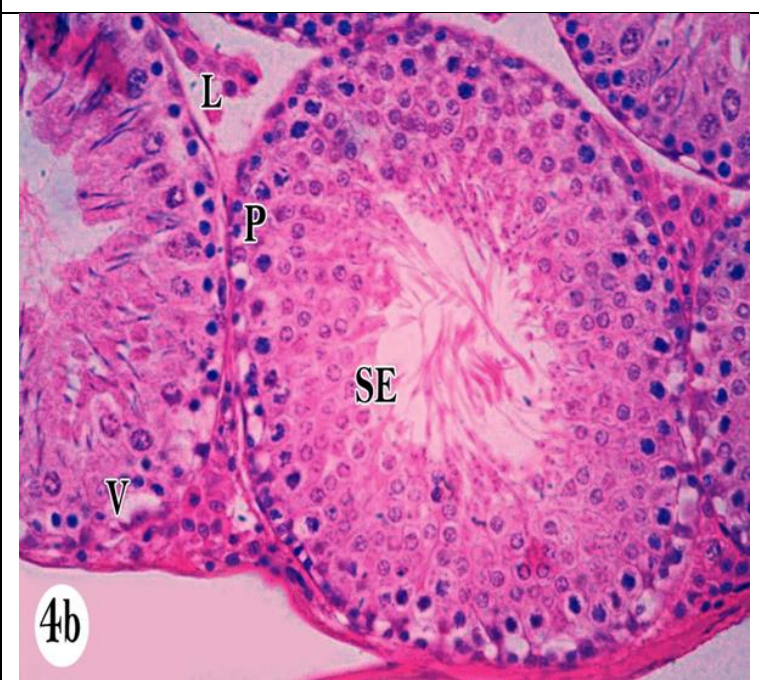

Figure (4b): Section in testis of a rat treated with MSG and Propolis showing organized spermatogenic lineage (S) with some vacuoles $(\mathrm{V})$ and cells with dense pyknotic nuclei $(\mathrm{P})$. Notice the preserved Leydig cells (L). (H\&E x400) 


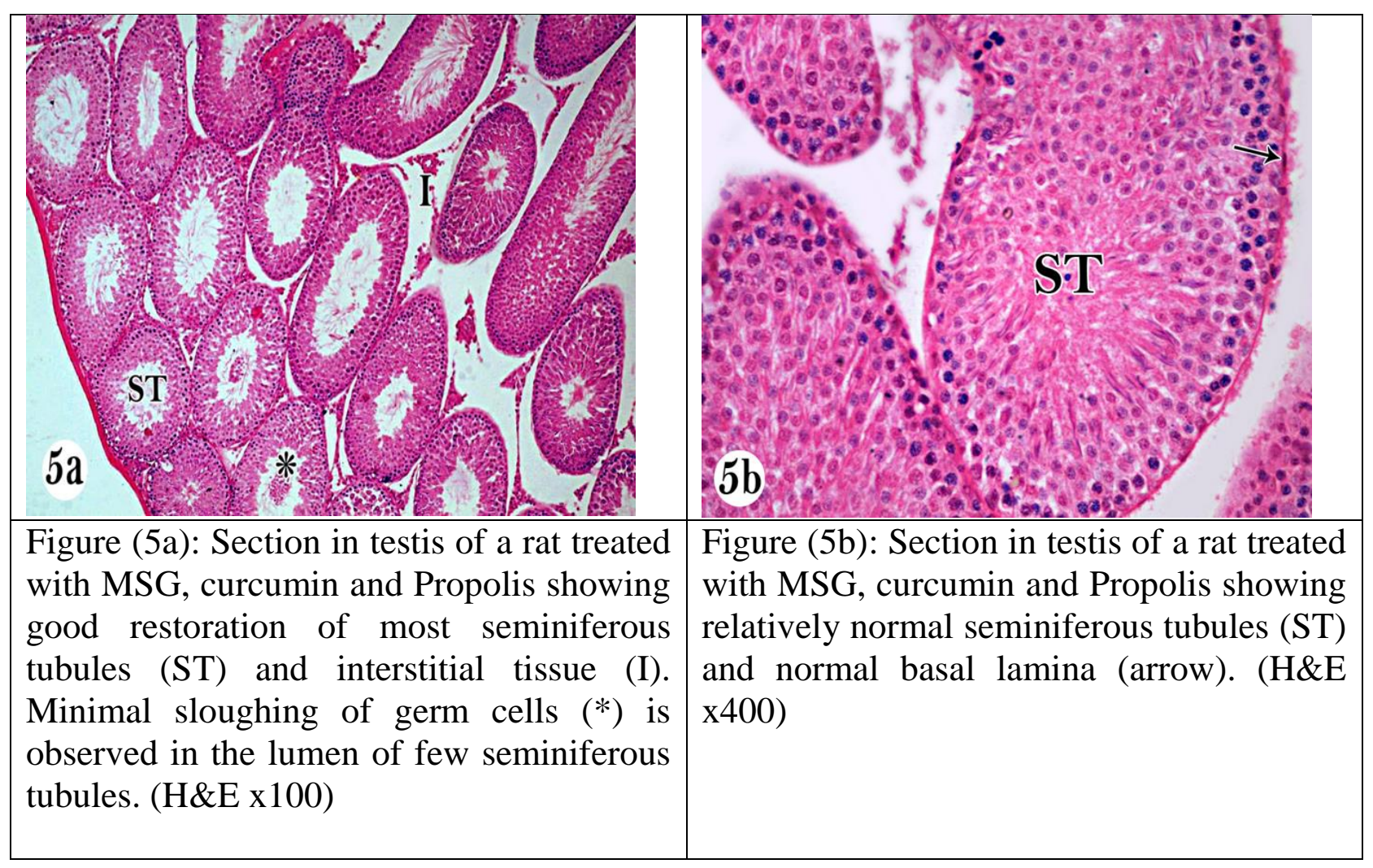

\section{DISCUSSION}

Monosodium glutamate (MSG) is one of the main flavor enhancer used in the food products which is known to affect the structure and function of male reproductive system and showed to be toxic to the testis of human and experimental animals as mentioned by Moore (2003).

In the present study, rats treated with MSG showed significant increased body weight compared with their age matched control in the first 3 weeks; this was in agreement with Rogers et al. (1990) who had reported that oral administration of MSG resulted in increased body weight of rats. Hermanussen and Tresguerres (2003) \& Hermanussen et al. (2006) explained that MSG caused increase body weight through stimulation of the orosensory receptors, MSG influenced the appetite positively, and induced weight gain or due to an improvement in the palatability of foods by exerting a positive influence on the appetite center. This may raise the idea that MSG administration affects positively the weight. Recent studies on healthy Chinese subjects reported that MSG consumption was positively linked to increased risk of overweight (He et al., 2008 and 2011). In the present work there was significant reduction in the body weight in rats treated with MSG for longer period (6ws) when compared to their age matched control groups, which indicated that the effect of MSG administration is temporary and not permanent. This was in accordance with Shi et al. (2010) who reported that MSG intake was not associated with a higher prevalence of obesity or with a clinically significant weight gain in Chinese adults. Other studies demonstrated that MSG 
did not increase food intake or induce obesity (Boutry et al., 2011), and some even demonstrated that MSG administration to rats was associated with suppression of body weight gain, fat deposition, and plasma leptin levels (Kondoh and Torii, 2008).

As reported by França et al. (2005) testis weight or size generally establishes the normalcy of testis. The present results showed that treating rats with MSG caused a decrease in the testis weight and sperm count. Moreover, histological results revealed damage of the seminiferous tubules together with degeneration of Leydig cells and inhibition of spermatogenesis. These results are in consistent with findings of other studies on the effect of MSG on testis. Nayatara et al. (2008) reported that treating rats with MSG reduce the sperm count and increase incidence of abnormal sperms. Ekaluo et al. (2013) reported that MSG-treatment caused reduction of testis and epididymis weight, sperm count and increase in sperm abnormalities. In addition, Onakewor et al. (1998) and Boodnard et al. (2001) mentioned that administration of MSG led to atrophic changes in the testis and destruction of sertolli cells and leydig cells.

In contrast with this finding, a previous study showed that the oral administration of $4 \mathrm{~g} / \mathrm{kg}$ of MSG did not affect the testicular morphology but caused reduction in caudal epididymal sperm counts in rats (Igwebuike et al., 2011).

MSG has been demonstrated to exert neuronal toxic effects in the central nervous system (CNS), including the hypothalamo-pituitary (HP) axis
(Samuels, 1999). Testosterone and LH hormones are essential for normal testis function and healthy spermatogenesis. The present study showed that administration of $4 \mathrm{~g} / \mathrm{kg}$ body weight of MSG significantly decreased the plasma testosterone and LH levels, such decrease may adversely affect the reproductive capacity of the affected animals. This was in agreement with França et al. (2005) who reported that plasma levels of gonadotropic hormones and testosterone, and the total number of Leydig cells significantly decreased in prepubertal rats treated with $4 \mathrm{mg} / \mathrm{kg}$ body weight of MSG. The present reduction in the plasma testosterone and LH levels may therefore be due to the disruption of the HP axis in the MSG treated rats. In addition, it is possible that the total number of Leydig cells responsible for testosterone production decreased, as there was marked shrinkage of the testicular interstitial tissues of the MSG groups compared to the control. The present decreased epididymal sperm concentration in rats treated with a high dose MSG (4 g/kg body weight) is consistent with previous studies of França et al. (2005) and Igwebuike et al. (2011).

Structurally, MSG had adverse effects on the testis of rats in the present work, where seminiferous tubules (ST) showed sloughing of the germinal epithelium with few sperms in their lumens. The basement membrane appeared irregular. The interstitial spaces appeared wide with intertubular hemorrhage and the Leydig cells were few. This is in agreement with previous studies, which mentioned that the MSG causes significant degeneration of ST 
with necrosis of spermatocytes, spermatids, in addition to epithelial sloughing and epithelial gaps (Akondi et al., 2011). These effects may be due to excessive glutamate dissociated from exogenously administered MSG rats may hyper-activate the mGlu receptors present in Sertoli cells (SCs), resulting in an excess of calcium influx, which may induce such testicular pathological changes as sloughing of SCs into the tubular lumen (Storto et al., 2001).

Previous studies reported that MSG was associated with the production of oxygen free radicals and oxidative stress in different tissues of experimental animals (Onyema et al., 2012; Kumar and Bhandari, 2013). Antioxidants play a major role in preventing the formation of free radicals, which are responsible for many oxidative processes leading to cell damage.

Many studies showed that Curcumin has antioxidant properties with a potent ability to inhibit reactive oxygen species formation (Biswas et al., 2005). Also propolis possesses antioxidant activity. This may be due to the free radical scavenging activity of propolis that protects sperm membrane from the deleterious action of oxidative attacks and reduces their barbituric acid reactive substances formation (Russo et al., 2006). Yousef and Salama (2009) also reported that propolis induces a significant increase in the level of antioxidant enzymes.

The results of the current work showed that with administration of curcumin and propolis separately with MSG, improvement occurred in testicular weight, sperm count and testosterone and LH plasma level and marked improvement was noticed after co-administration of both curcumin and propolis with MSG. This is in accordance with previous studies which mentioned that the administration of propolis caused significant improvement in sperm characteristics and male fertility of rats exposed to chlorpyrifos toxicity (El-Mazoudy et al., 2011). Sakr et al. (2013) reported that administration of curcumin to fluoxtine-treated rats was shown to ameliorate the testicular toxicity of fluoxtine and caused significant increase in $\mathrm{LH}$ and testosterone. Ilbey et al. (2009) reported that treating rats with curcumin improved the cisplatin-induced testicular injury. Curcumin was found to be useful for prevention of cadmium induced reproductive damage (Oguzturk et al., 2012). Propolis was found to be an important antioxidant and can be effective in the protection of triphenyltin induced reproductive toxicity (Yousef et al., 2010). Curcumin improved the decreased sperm count induced by cadmium in rats (Salama and El-Bahr, 2007). Co-administration of curcumin to monosodium glutamate treated rats increased the sperm count (Sakr et al., 2013). Also, Co-administration of curcumin significantly improved the daily sperm production in gallic acid induced testicular toxicity (Abarikwu et al., 2014).

The present study showed that structural changes were ameliorated and ST regained their normal germinal epithelium and Sertoli cells with intact basement membrane and presence of sperm bundles inside their lumens after co-administration of curcumin or propolis with MSG separately but 
marked improvement was noticed after administration of both curcumin and propolis with MSG, suggesting that curcumin and propolis caused improvement of spermatogenesis impairment by MSG toxic effect on the testis. These findings were in agreement with Sakr and Badawy (2013) on their study about protective effect of curcumin against the toxic effect of MSG on rat reproductive system. Also in agreement with the study of Fetouh and Azab (2014) about the protective effect of curcumin and propolis against reproductive toxicity of gentamicin.

The obtained histological and biochemical disturbances appeared as a result of the oxidative stress induced by MSG. The results showed that curcumin and propolis exerted a protective effect on MSG- induced testicular damage and this is probably due to its antioxidants properties. In conclusion, the present wok showed that MSG can affect the structure and function of testicular tissues and affect spermatogenesis. Curcumin and propolis has ameliorative effect on the testicular toxicity of MSG. This may be explained by the fact that it improve testicular weight, plasma testosterone and $\mathrm{LH}$, prevent cellular damage occurring as a result of oxidative stress in spermatogenic cells and Leydig cells.

Conflict of Interest: The authors certify no financial involvement and no conflicts of interest to report.

\section{REFERENCES}

Abarikwu, S.O; Akiri, O.F; Durojaiye, M.A. and Alabi, A.F. (2014): Combined administration of curcumin and gallic acid inhibits gallic acid-induced suppression of steroidogenesis, sperm output, antioxidant defenses and inflammatory responsive genes. J Steroid Biochem Mol Biol., 143(9):49-60.

Akondi, R.B.; Akula, A. and Challa, S.R. (2011): Protective effects of rutin and naringin on gentamicin induced testicular oxidative stress. Eu J Gen Med., 8(1):57-64.

Bankova, V.S; De Castro, S.L. and Marcucci, M.C. (2000): Propolis: recent advances in chemistry and plant origin. Apidologie., 31(1):315.

Beyreuther, K.; Biesalski, H.K.; Fernstrom, J.D.; Grimm, P.; Hammes, W.P.; Heinemann, U. et al.(2007): Consensus meeting: monosodium glutamate - an update. Eur J Clin Nutr., 61(3):304-13.

Biswas, S.K.; McClure, D.; Jimenez, L.A.; Megson, I.L. and Rahman, I. (2005): Curcumin induces glutathione biosynthesis and inhibit NF-kappa B activation and interleukin-8 release in alveolar epithelial cells. Mechanism of free radical scavenging activity. Anti Red Sign., 7(1-2): 32-41.

Boodnard, I.; Gooz, P.; Okamura, H.; Toth, B.E.; Halasz, B. and Nagy, G.M. (2001): Effect of neonatal treatment with monosodium glutamate on dopaminergic and DOPA neurons of the medial basal hypothalamus and on prolactin and MSH secretion of rats. Brain Res. Bull., 55(6):767-774.

Boutry, C.; Bos, C.; Matsumoto, H.; Even, P.; AzzoutMarniche, D.; Tome, D. and Blachier, F. 
(2011):Effects of monosodium glutamate supplementation on glutamine metabolism in adult rats. Front Biosci., 1(3): 279-290.

Ekaluo, U.B.; Ikpeme, E.V.; Ibiang, Y.B. and Amaechina,O.S. (2013): Attenuating Role of Vitamin $\mathrm{C}$ on Sperm Toxicity Induced by Monosodium Glutamate in Albino Rats. Pakistan J. Of Biological Sci., DOI:10.3923/pjbs.

El-Mazoudy, R.H.; Attia, A.A. and ElShenawy, N.S. (2011): Protective role of propolis against reproductive toxicity of chlorpyrifos in male rats. Pestic Biochem Physiol ., 101(3): 175-181

Farombi, E.O.; Abarikwu,S.O.; Adedara, I.A. and Oyeyemi,M.O. (2007): Curcumin and kolaviron ameliorate di-n-butylphthalateinduced testicular damage in rats. Basic Clin Pharmacol Toxicol., 100(1): 43-8.

Fetouh, F. A. and Azab, E. A. (2014): Ameliorating effects of curcumin and propolis against the reproductive toxicity of gentamicin in adult male guinea pigs: Quantitative analysis and morphological study. American Journal of Life Sciences., 2(3): 138149.

França, L.R.; Suescun, M.O.; Miranda, J.R.; Giovambattista, A.; Perello, M.; Spinedi, E. et al. (2005): Testis structure and function in a nongenetic hyperadipose rat model at prepubertal and adult ages. Endocrinol., 147(3):1556-1563.

He, K.; Zhao, L.; Daviglus, M.L.; Dyer, A.R.; Van Horn, L.; Garside, D.; Zhu, L.; Guo, D.; Wu, Y.; Zhuo, B. and Stamler, J.
(2008): Association of monosodium glutamate intake with overweight in Chinese adults: the INTERMAP Study. Obesity., 16(8): 1875-1880.

He, K.; Du, S.; Xun, P.; Sharma, S.; Wang, H.; Zhai, F. and Popkin, B. (2011): Consumption of monosodium glutamate in relation to incidence of overweight in Chinese adults. China Health and Nutrition Survey (CHNS). Am J Clin Nutr., 93(6): 1328-1336.

Heeba, G.H. and Abd-Elghany, M.I. (2010): Effect of combined administration of ginger (Zingiber Officinale Roscoe) and atorvastatin on the liver of rats. Phytomedicine., 17(14): 1076-1081.

Hermanussen, $M$. and Tresguerres, J.A. (2003): Does high glutamate intake cause obesity? J Pediatr Endocrinol Metab., 16(7): 965-968.

Hermanussen, M.; Garcia, A.P.; Sunder, M.; Voigt, M.; Salazar, V. and Tresguerres, J.A. (2006): Obesity, voracity, and short stature: the impact of glutamate on the regulation of appetite. Eur $\mathrm{J}$ Clin Nutr., 60(1): 25-31.

Hu, J.H.; Yang, N.; Ma, Y.H.; Jiang, J.; Zhang, J.F.; Fei, J. et al.(2004): Identification of glutamate receptors and transporters in mouse and human sperm. J. Androl., 25(1):140-146.

Igwebuike, U.M.; Ochiogu, I.O.; Ihedinihu, B.C.; Ikokide, J.E. and Idika, I.K.(2011): The effects of oral administration of monosodium glutamate (msg) on the testicular morphology and cauda epididymis sperm reserves of young and adult male rat. Vet Arhiv., 81(4):525-534. 
Ilbey, Y.O.; Ozbek, E.; Cekmen, M.; Simsek, A.; Otunctemur, A. and Somay, A. (2009): Protective effect of curcuminin in cisplatin-induced oxidative injury in rat testis: mitogen-activated protein kinase and nuclear factor-kappa B signaling pathways. Hum Reprod., 24(7): 1717-25.

Jasprica, D.; Mornar, A.; Debeljak, Z.; Smolcic-Bubalo, A.; MedicSaric, M.; Mayer, L. et al.(2007): In vivo study of propolis supplementation effects on antioxidative status and red blood cells. J Ethnopharmacol., 110(3):548-554.

Khalil, M.L. (2006): Biological activity of bee propolis in health and disease. Asian Pac. J Cancer Prev., 7(1):2231.

Kondoh, T. and Torii, K. (2008): MSG intake suppresses weight gain, fat deposition, and plasma leptin levels in male Sprague-Dawley rats. Physiol Behav., 95(1-2): 135-144.

Kumar, P. and Bhandari, U. (2013): Protective effect of Trigonella foenum-graecum Linn. on monosodium glutamate-induced dyslipidemia and oxidative stress in rats. Indian J Pharmacol., 45(2): 136140.

Mazumder, A.; Raghavan, K.; Weinstein, J.; Kohn, K.W. and Pommier,Y. (1995): Inhibition of human immunodeficiency virus type-1 integrase by curcumin. Biochem Pharmacol., 49(8): 11651170.

Material Safety Data Sheet (MSDS) (2013): L-Glutamic acid, sodium salt. SPECTRUM Laboratory Products INC. 1-5.

Moore, K.L. (2003): Congenital malformations due to environmental factors. In Developing Humans. 2nd ed. Philadelphia: W.B. Saunders Co. Ltd; pp. 173-183.

Nayatara, A.K.; Vinodini, N.A.; Damodar, G.; Ahmed, B.; Ramaswamy, C.R. and Shabarienth, S. (2008): Role of ascorbic acid in monosodium glutamate mediated effect on testicular weight, sperm morphology and sperm count in rat testis. Journal of Chinese clinical Medicine., 3(1):1-5.

Oguzturk, H.; Ciftci, O.; Aydin, M.; Timurkaan, N.; Beytur, A. and Yilmaz, F. (2012): Ameliorative effects of curcumin against cadmium toxicity on male reproductive system in rats. Andrologia., 44(4):243-249

Onakewor, J.U.E.; Oforofuo, I.A.O. and Singh, S.P. (1998): Chronic administration of monosodium glutamate induces oligozoospermia and glycogen accumulation in Wister rat testis. Africa J. Reprod. Health., 2(2):190-197.

Onyema, O.O.; Aisil, C.S. and Ihetuge,A.P. (2012): Monosodium Glutamate Induces Oxidative Stress and Affects Glucose Metabolism in the Kidney of Rats. International Journal of Biochemistry Research \& Review., 2(1): 1-11.

Pari ,L.; Tewas,D. and Eckel,J. (2008): Role of curcumin in health and disease. Arch Physiol Biochem., 114(2): 127-49.

Rogers, P.P.; Blundell, J.E. and Umani, N. (1990): Umami and 
appetite: Effects of monosodium glutamate on hunger and food intake in human subjects. Physiol. Behav., 48(6): 801-804.

Ruby, A.J.; Kuttan, G.; Babu, K.D. and Kuttan, R. (2005): Anti-tumor and anti-oxidant activity of natural curcuminoids. Cancer Lett., 94(1): 79-83

Russo, A.; Troncoso, N,; Sanchez, F.; Garbarino, J.A. and Vanella, A.(2006): Propolis protects human spermatozoa from DNA damage caused by benzo[a]pyrene and exogenous reactive oxygen species. Life Sci., 78(13):1401-1406.

Sakr, S.A. and Badawy, G.M. (2013): Protective effect of curcumin on monosodium glutamate-induced reproductive toxicity in male rats. Global Journal of Pharmacology., 7(4):416-422.

Sakr, S.A.; Mahran, H.A. and ElDeeb, M.M. (2013): Ameliorative effect of curcumin on fluoxetineinduced reproductive toxicity and oxidative stress in male albino rats. Oxidants and Antioxidants in Medical Science., 2(1): 29-35.

Salama, A.F. and El-Bahr, S.M. (2007): Effect of curcumin on cadmium-induced oxidative testicular damage in rats. JMRI., 28(2):167-73.

Samuels, A. (1999): The toxicity/safety of MSG; A study in suppression of information. Account Res., 6(4):259310.

Sengupta, P. A. (2011): Scientific Review of Age Determination for a Laboratory Rat: How old is it in comparison with Human age? Biomed Int., 2(2):81-89.
Seo, H.J.; Ham, H.D.; Jin, H.Y.; Lee, W.H.; Hwang, H.S.; Park, S.A. et al. (2010): Chronic administration of monosodium glutamate under chronic variable stress impaired hypothalamic-pituitary-adrenal axis function in rats. Korean $\mathrm{J}$ Physiol Pharmacol., 14(4):213-21.

Shi, Z.; Luscombe-Marsh, N.D.; Wittert, G.A.; Yuan, B.; Dai, Y.; Pan, X. and Taylor, A.M. (2010): Monosodium glutamate is not associated with obesity or a greater prevalence of weight gain over 5 years: findings from the Jiangsu Nutrition Study of Chinese adults. $\mathrm{Br}$ J Nutr., 104(3): 457-463.

Sobocanec, S.; Sverko,V; Balog, T.; Saric, A.; Rusak, G.; Likic, S. et al. (2006): Oxidant/antioxidant properties of Croatian native propolis. J Agric Food Chem., 54(21):8018-8026.

Storto, M.; Sallese, M.; Salvatore, L.; Poulet, R.; Condorelli, D.F.; Dell'Albani, P. et al.(2001): Expression of metabotropic glutamate receptors in the rat and human testis. J Endocrinol., 170(1):71-8.

Ströfer, M.; Jelkmann, W. and Depping, R. (2012): Curcumin decreases survival of Hep3B liver and MCF-7 breast cancer cells: the role of HIF. Strahlenther Onkol., 187(7): 393-400.

Walker, R. and Lupien, J.R. (2000): The safety evaluation of monosodium glutamate. J Nutr. ,130(4S Suppl):1049S-1052S.

Yousef, M.I. and Salama, A.F.(2009): Propolis protection from reproductive toxicity caused by 
aluminum chloride in male rats. Food Chem. Toxic., 47(6): 11681175.

Yousef, M.I.; Kamel, K.I.; Hassan, M.S. and El-Morsy, A.M. (2010):
Protective role of propolis against reproductive toxicity of triphenyltin in male rabbits. Food Chem Toxicol., 48(7):1846-1852. 


\title{
سمية الجلوتامات أحادية الصوديوم على الجهاز التناسلى فى ذكر الجرزان وتأثير تزامن تعاطيه مع الكركم و البروبوليس التيل فئس
}

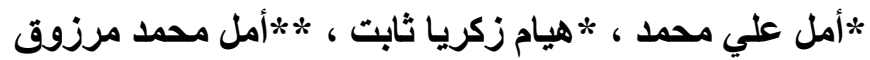 \\ *قسم الطب الثرعي والسموم الإكلينيكية_** قسم الهستولوجى - كلية الطب - جامعة أسيوط
}

اثارت سلامة استخدام الجلوتامات أحادية الصوديوم الكثير من الجدل محليا وعالميا وليا ومن المعروف

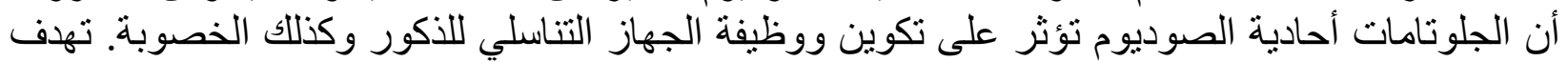

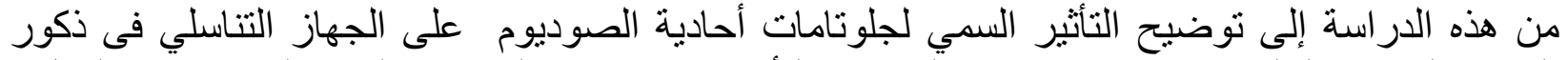

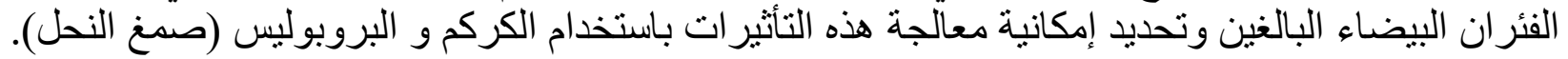

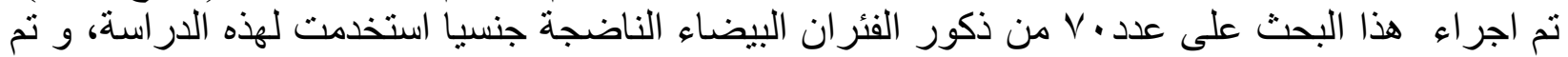

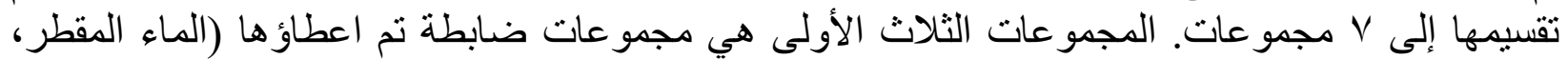

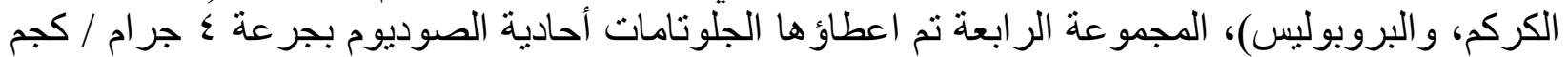

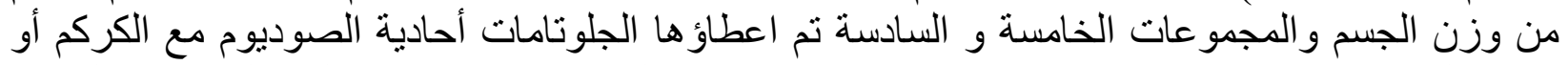

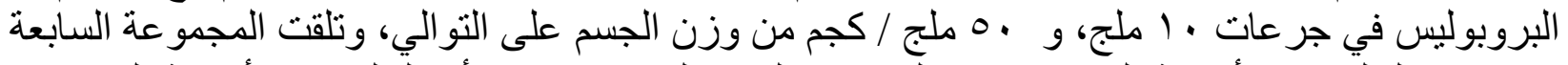

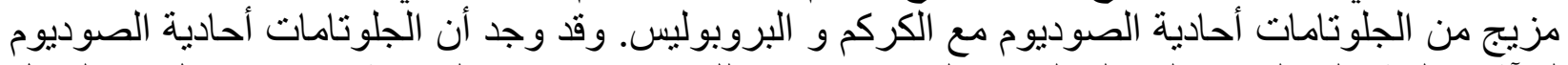

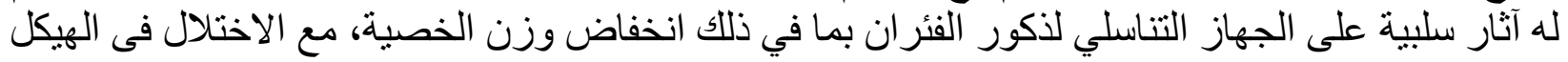

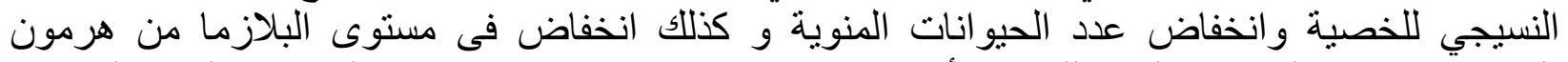

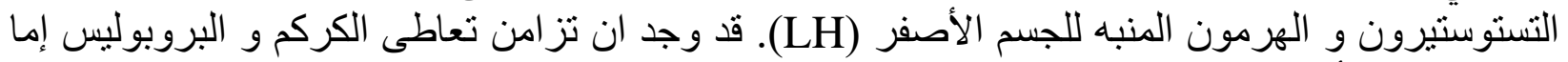

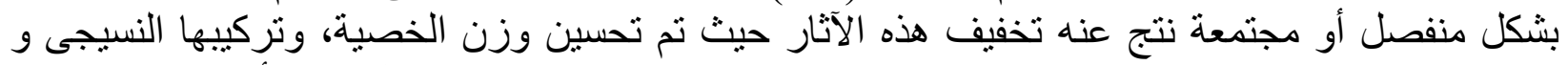
كذللك عدد الحيو انات المنوية ومستويات هرمون التسنوستيرون و الهرمون المنبه للجسم الأصفر (LH) 